\title{
Okuduğunu Anlama Stratejilerinin Okuduğunu Anlamaya Etkisi: Bir Meta-Analiz Çalışması
}

\section{The Effect of Reading Comprehension Strategies on Reading Comprehension: A Meta-Analysis Study}

\author{
Sabri SİDEKLI ${ }^{1}$, Esra ÇETİN ${ }^{2}$
}

\begin{abstract}
Öz: Bu araştırmada okuduğunu anlama stratejilerinin öğrencilerin okuduğunu anlamalarına etkisini deneysel yöntemlerle ortaya koyan çalışmaların etki büyüklüklerinin birleştirilmesi amaçlanmıştır. Okuduğunu anlama stratejilerinin etkisinin tez türüne, yıllara, örneklemdeki öğrencilerin öğrenim düzeylerine, uygulanan toplam öğretim sürelerine göre farklılık gösterip göstermediğine meta-analiz yöntemiyle bakılmıştır. Hangi araştırmaların metaanalize dâhil edileceğine yönelik seçimlerin yapılmasında belirli ölçütler kullanılmıştır. Bunlar; 2000 ile 2015 yılları arasında yapılmış lisansüstü tez olması, araştırmaların deney ve kontrol gruplarının olması, örneklem büyüklükleri, standart sapma ve aritmetik ortalamalarının olması, sınırlılı̆g 1 dördüncü sınıf ve beșinci sınıf olan araştırmalar olmasıdır. Deneysel metaanalizde Comprehensive Meta Analysis (CMA) programından yararlanılmıştır. İlk önce heterojenlik testi yapılmıştır. Heterojenlik testine göre analizin rastgele etkiler modeli altında yapılması gerekmektedir. Yapılan analizler sonucunda okuduğunu anlama stratejilerinin geleneksel yönteme kıyasla daha etkili olduğu bulunmuştur.
\end{abstract}

Anahtar sözcükler: Okuğunu anlama, okuma, anlama stratejisi, meta-analiz-

\begin{abstract}
In this study, the effects of some studies that examine the effects of reading comprehension on learners' reading comprehension ability are aimed to be come together. Additionally, effect size of these studies is examined in terms of learners' reading comprehension strategies, thesis types, theses' years and teaching process differences with the help of a meta-analysis method. While determining the studies covered in the meta-analysis method, some different criteria are used. These are, firstly, the years of a study; that is in this study, the experimental studies conducted between 2000-2015 years are used. Secondly, studies consisting of an experimental group and control group are selected. Additionally, the studies having enough sample and universe, standard deviation, arithmetic mean and the studies just conducted in 4. and 5. grade students are determined for this study. As for experimental meta-analysis, Comprehensive Meta - Analysis (CMA) program is used. With the help of CMA 2.2 program, firstly heterogeneousness test is completed. According to heterogeneousness test, the analysis could be conducted in random-facts model. As a result of the analysis, it is seen that reading comprehension strategies is more effective than the traditional models. All of the studies analyzed in this
\end{abstract}

\footnotetext{
${ }^{1}$ Doç. Dr., Muğla Sitkı Koçman Üniversitesi, e-posta: ssidekli@mu.edu.tr

${ }^{2}$ Yüksek Lisans Öğrencisi, Muğla Sıtkı Koçman Üniversitesi, e-posta: esractn_48@windowslive.com
} 
study suggest that reading comprehension strategies supports reading comprehension skills.

Keywords: Reading comprehension, reading, comprehension strategy, meta-analysis

\section{GİRIŞ}

Okuma ve anlama becerileri öğrencilerin yaşam boyu kullanacakları ve kendilerini sürekli geliştirecekleri becerilerin başında gelmektedir. Bu becerilerin geliştirilmesi sadece Türkçe öğretimi derslerinde değil diğer derslerde de ayrı bir önem taşımaktadır. Çünkü okuma ve anlama becerilerine sahip olmayan öğrencilerin akademik başarılarının düşük olacağı bilinmektedir (Sidekli, 2005).

Okuma, yazıyı, sözcükleri, cümleleri, noktalama işaretleri ve öteki öğeleriyle görme, algılama ve kavrama surecidir. Okuma, bilisel davranışlarla psikomotor becerilerin çalışmasıyla, yazılı sembollerden anlam çıkarma etkinliğidir (Razon, 1980). Okuma süreci görme, algılama, seslendirme, anlama, zihinde yapılandırma gibi beynin çeşitli işlemlerinden oluşan karmaşık bir süreçtir. Bu süreç çizgi, harf veya sembollerin algılanmasıyla başlamaktadır. Algılama işleminin ardından dikkat yoğunlaşarak kelimeler tanınmakta ve cümleler anlaşılmaktadır. Seçilen bilgiler sıralama, sınıflama, ilişkilendirme, sorgulama, analiz, sentez, değerlendirme gibi çeşitli zihinsel işlemlerden geçirilmektedir. Bu şekilde işlenen bilgi okuyucunun ön bilgileriyle birleştirilerek yeniden anlamlandırılmaktadır (Güneş, 2009).

Okumanın temel amacı öğrencilere, dünyayı ve kendilerini anlamalarını, beklenti ve ilgilerini geliştirmelerini ve bağımsız anlayıcılar olmalarını sağlayan strateji ve teknikler geliştirmelerini sağlamaktır. Anlama, okuma öğretiminin en önemli parçası olarak düşünülebilir ve bu öğretimin asıl amacı öğrencilerin düşünmesini ve okuduklarına tepki vermesini sağlamak; kısaca anlamak için öğrenmelerini sağlayan öğrenme aktivitelerinin hazırlanmasıdır (NRP, 2000). Pardo (2004), okuduğunu anlamayı öğrencinin metin ile etkileşimi esnasında, metnin içeriği ve iletisi ile kendi ön bilgi ve becerilerini bütünleyerek anlamı yapılandırma süreci olarak tanımlar. Kavcar, Oğuzkan ve Sever (1994) ise okuduğunu anlamay1; yazılı olan şeyleri algılama, anlamlandırma ve kavrama, aktarılmak istenen bilgi, duygu, ve düşüncelerin olduğu gibi, bir yanlışlığa yol açmadan, kendi akısı içinde ve hiçbir şüpheli nokta kalmayacak bicimde bütün boyutları ile kavranılması olarak ifade etmektedir.

Uluslararası Öğrenci Performansı Değerlendirme testine yani PISA (2015) araştırmasına Türkiye de dâhil olmak üzere 72 ülke katılmıştır. Bu araştırmada Türkiye okuma başarı sıralamasında 72 ülke arasından 50. sırada olduğu tespit edilmiştir.

Okuma ve okuduğunu anlama arasında önemli bir ilişsi bulunmaktadır. İnsanın nasıl öğrendiği, bilgiyi nasıl inşa ettiği bilinirse ona uygun bir öğrenme ortamı oluşturulabilir (Sidekli, 2010). Bu nedenle okuma ve okuduğunu anlama becerisini geliştirmeye yönelik çalışmaların gerekliliği vurgulanmakta ve önemi artmaktadır.

Okuyucular anlamayı kolaylaştırmak için okuma öncesi, okuma sırası, ve okuma sonrasında etkin olması, birçok strateji ve tekniği kullanabilmesi önemlidir. İyi bir okuyucu okuma öncesinde bir amaca sahiptir, metni gözden geçirir, ana hatlarıyla tarar, metinde nelerden söz edildiği hakkında hipotezler ileri sürer (Epçaçan, 2008). Aynı zamanda okuduğunu anlama stratejileri öğrencilere, ön bilgileri ile metinden öğrendikleri bilgileri birleştirme konusunda yardımcı olur. 
Okuma stratejilerinin diğer faydası da öğrencilerin akademik başarılarını olumlu yönde etkilemesidir. Öğrenciler okuma stratejilerini uygulamakla metinleri daha etkili bir şekilde anlayabilir ve bir sonraki metne daha iyi hazırlık yapabilirler (Gürses, 2002, s. 23).

\subsection{Problem}

Lisansüstü tezlerde uygulanan okuduğunu anlama stratejilerinin okuduğunu anlamaya etkisi nedir?

\subsection{Araştırmanın Amacı}

$\mathrm{Bu}$ araştırmanın amacı, sınıf öğretmenliği eğitimi alanında yapılmış okuduğunu anlamaya yönelik lisansüstü tezlerin meta analizini yapmaktır.

Araştırmanın amacı doğrultusunda şu sorulara cevap aranmıştır:

1. Lisansüstü tezlerde uygulanan okuduğunu anlama stratejilerinin okuduğunu anlamaya etkisi nedir?

2. Okuduğunu anlama stratejilerinin etki büyüklükleri,

2.1. Tezlerin yapıldığg yıla,

2.2. Tez türüne,

2.3. Örneklemdeki öğrencilerin öğrenimdüzeyine

\subsection{Araştırmanın Önemi}

2.4. Uygulanan toplam öğretim sürelerine göre değişmekte midir?

Araştırmada, okuduğunu anlama üzerinde yapılmış araştırmaların bulguları meta-analiz yöntemiyle birleştirilmiştir. Araştırmada okuduğunu anlama stratejilerinin etkililiği üzerine genel yargılara ulaşılabilmesi planlanmıştır. Kullanılan yöntemlerin geleneksel yönteme kıyasla ne derece etkili olduğu açık ve net bir şekilde ortaya konmaya çalışılmıştır. Okuduğunu anlama alanında yapılan deneysel çalışmalardan ulaşılabilenlerinin sonuçları üzerine genel yargılara varmak amaçlanmıştır.

Ayrıca, araştırmanın yöntemi olan meta analitik literatür tarama yöntemi Türkiye'de tıp alanında kullanılmakla birlikte, diğer alanlarda henüz yaygınlaşmamıştır (Şahin, 2005). Meta-analiz yöntemi, yurtdışında eğitim alanında da yaygın bir şekilde kullanılmaktadır (Igel, 2010). Araştırmanın, okuma kalitesinin yükseltilmesine yardımcı olacağı ve öğretmenlere uygulayabilecekleri öğretimyöntem ve teknikleri açısından fikir vereceği düşünülmektedir.

\section{YÖNTEM}

Araştırmada meta-analiz yöntemi kullanılmıştır. Meta-analiz yönteminin kullanılmasının temel nedenlerinden birisi 4 ve 5.sınıflarda okuduğunu anlama becerisini geliştirmeye yönelik yapılmış olan araştırmaların bulgularını birleştirerek genel bir yargıya varmayı sağlamaktır. Meta-analiz Durlak'a (1995) göre belirlenen bir konuda yapılmış, bağımsız ve birçok araştırmanın sonuçları kullanılarak elde edilen bulguların analizini yaparak yeniden yorumlama yöntemidir. Bu yöntem, daha önceden yapılan deneysel araştırma sonuçlarını ele alarak araştırmacılara nicel veriler sunmakta; tüm araştırmaların sonuçlarını birleştirerek genel bir sonuç ortaya çıkmasını ve araştırmanın istatistiksel anlamlılık düzeyini artırarak sonuçlar hakkında daha net bir ifadeye ulaşmayı sağlayabilmektedir (Dinçer, 2014; Sağlam \& Yüksel, 2007). 
Ayrıca meta-analiz yöntemi yapılmış olan araştırmalarda okuduğunu anlama stratejilerinin etkililikleri arasında farklılaşmanın olup olmadığını ortaya koymaktadır. Bir alandaki birden çok araştırmanın sonuçlarının birleştirilerek incelenmesi, benzer sonuçlara ulaşan diğer araştırmaların geçerliliğini arttırabilmesi, meta-analiz araştırmalarının en önemli özelliği olarak ele alınabilmektedir (Abramson \& Abramson, 2001; Sağlam \& Yüksel, 2007).

\subsection{Verilerin Toplanması}

Araştırma sorularına cevap aramak için YÖK'ün ulusal tez merkezinden yararlanılmıştır. Tezler 'okuduğunu anlama' ve ‘okuma anlama' anahtar kelimeleriyle taranmıştır. Anahtar kelimelerle yapılan araştırma ile elde edilen araştırmalar, analize uygun veriler içeriyorsa meta-analiz yöntemine dâhil edilmiştir.

Bir araştırmanın meta-analize dâhil edilebilmesi için amaca uygun verileri içermesi gereklidir (Özcan, 2008). Bu meta-analiz araştırmasında kullanılan araştırmaların seçim kriterleri şunlardır:

- Okuduğunu anlama alanında 2000 ile 2015 yılları arasında yapılmış lisansüstü tezler,

- Araştırmaların deney ve kontrol gruplarının olması,

- Örneklem büyüklükleri, standart sapma ve aritmetik ortalamalarının olması,

- Sinırlılığı dördüncü sınıf ve beşinci sınıf olan araştırmalar olması.

Bulunan 115 adet tez içinden deneysel araştırmalara odaklanılarak özellikle son test uygulanan ve gruplar arasında karşılaştırma yapılan tezler, ilgili araştırma için seçilmiştir. Meta-analiz araştırmaları için gerekli olan değişkenlere (n, $x$, ss vb.) sahip olmayan araştırmalar elenmiştir. Sonuç olarak belirlenen seçim özelliklerine göre araştırmaya 24 lisansüstü tez dâhil edilmiştir. Bu araştırmaların bazılarında birden fazla okuduğunu anlama stratejisinin etkisine bakıldığı için araştırma verilerinin içerisine 27 araştırmaya yönelik sonuçlar eklenmiştir.

Araştırma kapsamında yer alan araştırmalar bir kodlama formu kullanılarak kodlanmıştır. Kodlama formunda araştırmanın yazarı, yılı, hangi üniversitede yapıldığı, türü, hangi sınıf düzeyinde gerçekleştirildiği, araştırmada kullanılan yöntem, deney ve kontrol grubundaki örneklem büyüklüğ̈̈, son test puanları ve standart sapmaları yer almaktadır.

Araştırmaya dâhil edilen 24 tezin 11 'i yüksek lisans 13'ü doktora tezidir. $\mathrm{Bu}$ tezlerden uygulamanın yapıldığı öğrenim düzeyi dördüncü sınıf olan 9 çalışma, beşinci sınıf olan 15 çalışma mevcuttur. Örneklemi beşinci sınıf olan araştırmalar 4+4+4 eğitim sistemi değişikliği yapılmadan önce uygulanmıştır.

\subsection{Verilerin Analizi}

Araştırmada betimsel analiz ve deneysel meta analiz yöntemi kullanılmıştır. Betimsel analizde, araştırmaların üretildiği yıllar, araştırmanın türü, üniversiteler ve uygulanan yöntemlere göre frekans değerlerinin analizleri bulunmuştur. Deneysel meta-analizde Comprehensive Meta Analysis (CMA) programından yararlanılmıştır. Etki büyüklügüünün deney ve kontrol gruplarına bağlı olarak hesaplandığı bu analizde etki büyüklüğü gruplar arasındaki ortalama fark anlamına gelmektedir (Malofeeva, 2005'ten akt. Çelik, 2013, s. 58). 
Meta analiz sonucunda elde edilen etki büyüklüklerinin önemini yorumlarken sınıflandırmalar kullanılır. Sınıflandırma şu ölçütlere göre oluşturarak yorumlanmıştır (Cohen, 1988):

$\begin{array}{llll}-0.15 \leq d<0.15 & \text { önemsiz düzeyde } & 0.75 \leq d<1.10 & \text { geniş düzeyde } \\ 0.15 \leq d<0.40 & \text { küçük düzeyde } & 1.10 \leq d<1.45 & \text { çok geniş düzeyde } \\ 0.40 \leq d<0.75 & \text { orta düzeyde } & 1.45 \leq d & \text { mükemmel düzeyde }\end{array}$

Meta-analize getirilen en büyük eleştirilerden biri dâhil edilen araştırmaların yanlı çıkma düşüncesidir. Bu yanlılığın ortadan kaldırılabilmesi için etki büyüklügünü sıfır yapacak kaç tane araştırmanın analize dâhil edilmesi gerektiği hesaplanmalıdır (Özcan, 2008). Bu sayı meta-analiz araştırmasında bulunan etki büyüklügüün̈ geçersiz hale getirecek kadar zıt yönlü değerlere sahip çalışma sayısını göstermektedir. Alanyazında bu sayıda çalışma bulunduğunda meta-analiz bulguları geçersiz olacaktır (Okursoy Günhan, 2009). Araştırmada elde edilen bu sayı Rosenthal yöntemi ile 2979'dur. 27 çalışmanın dâhil edildiği bu araştırmanın bulgularının geçersiz sayılabilmesi için alanyazında 2979 tane zıt bulgulara sahip çalışmanın olması gerekmektedir. Yayın yanlılığından yeterince uzaklaşabilmek için bu sayının ne kadar büyük olması gerektiğiyle ilgili kesin bir kural bulunmamasına rağmen, Mullen, Muellerleile ve Bryant (2001), Rosenthal'ın önerisini temel alarak, N/(5k+10) (burada $\mathrm{k}$, meta-analize dâhil edilen çalışma sayısıdır) değerinin 1'i geçmesi durumunda, meta-analizin sonuçlarının gelecekteki çalışmalar için yeterince dirençli göründüğü sonucuna ulaşılabileceğini önermişlerdir. Buna göre $\mathrm{N}(5 \mathrm{k}+10)$ oranı 19.2 olarak hesaplanmaktadır ve bu değer çalışmaların yayın yanlılığına karşı oldukça dirençli olduğunu göstermektedir.

\section{BULGULAR}

Okuduğunu anlama ile ilgili araştırmalardan örneklem sayısı, aritmetik ortalamaları ve standart sapmaları verilen 24 (27 adet araştırma bulgusu olarak) lisansüstü tezlerine ait genel karakteristikler tablolar halinde sunulmuştur. 24 adet araştırmanın toplamı düşünüldüğünde deney grubu 886, kontrol grubu 721 öğrenciden oluşmaktadır.

Tablo 1. Okuduğunu anlama alanında yapılan tezlerin üniversitelere göre dağılımı

\begin{tabular}{llll}
\hline Üniversite & & Yüksek Lisansans & Doktora \\
\hline Çukurova Üniversitesi & 2 & & - \\
Mustafa Kemal Üniversitesi & 2 & & - \\
Adnan Menderes Üniversitesi & 2 & & 7 \\
Gazi Üniversitesi & - & 1 \\
Firat Üniversitesi & - & 1 \\
Hacettepe Üniversitesi & - & 1 \\
Anadolu Üniversitesi & - & 2 \\
Dokuz Eylül Üniversitesi & 2 & - \\
Bülent Ecevit Üniversitesi & 1 & & 1 \\
Ankara Üniversitesi & - & & - \\
Akdeniz Üniversitesi & 1 & & - \\
Selçuk Üniversitesi & 1 & $\mathbf{1 3}$ \\
\hline Toplam & $\mathbf{1 1}$ & \\
Genel Toplam & & $\mathbf{2 4}$ & \\
\hline
\end{tabular}


Okuduğunu anlamaya yönelik tezlerin Çukurova Üniversitesi, Mustafa Kemal Üniversitesi, Adnan Menderes Üniversitesi, Gazi Üniversitesi, Frrat Üniversitesi, Hacettepe Üniversitesi, Anadolu Üniversitesi, Dokuz Eylül Üniversitesi, Bülent Ecevit Üniversitesi, Ankara Üniversitesi, Akdeniz Üniversitesi ve Selçuk Üniversitesinde üretildiği ve 24 tezin 7'sinin Gazi Üniversitesi'nde yapılan doktora tezi olduğu görülmüştür.

Okuduğunu anlama sürecinde kullanılan farklı yöntemlerin okuduğunu anlamaya etkisini belirlemeyi amaçlayan bu araştırmada etki büyüklüklerinin hesaplanmasında deney ve kontrol gruplarının örneklem büyüklükleri, standart sapmaları ve son test puan ortalamaları kullanılmıştır. Hedges's tarafından geliştirilen yöntemle çalışmaların etki büyüklükleri bulunmuş ve CMA 2.2 programı yardımıyla ilk önce heterojenlik testi yapılmıştır. Heterojenlik testi sonucunda elde edilecek bilgi, genel etkinin hesaplanmasında kullanılacak modelin seçiminde kullanılacağından oldukça önemlidir. Heterojenlik testi sonucunda $p$ değeri 0,05 'ten küçük ya da $Q$ değeri ki-kare tablosunda $d f$ değerine karşılık gelen değerden büyük ise analize dâhil edilen bireysel çalışmalar sonucunda meta-analiz uygulamasının heterojen bir yapıda olduğu anlaşılmıştır. Yani bu çalışmalar benzer yapıda değillerdir. Bu durumda analizin rastgele etkiler modeli altında yapılması gerekmektedir. Aksi takdirde sabit etkiler modeli kullanılır (Dinçer, 2014).

Tablo 2. Etki modellerine göre meta-analiz çalışması sonuçlarının karşılaştırılması

\begin{tabular}{|c|c|c|c|c|c|c|c|c|}
\hline \multirow[b]{2}{*}{ Model } & \multirow[b]{2}{*}{$N$} & \multirow[b]{2}{*}{$z$} & \multirow[b]{2}{*}{$p$} & \multirow[b]{2}{*}{$Q$} & \multirow{2}{*}{$\begin{array}{l}\text { Ki- } \\
\text { Kare } \\
\text { tablo } \\
\text { değeri }\end{array}$} & \multirow{2}{*}{$\begin{array}{l}\text { Etki } \\
\text { Büyükl } \\
\text { üğ̈̈ }\end{array}$} & \multicolumn{2}{|c|}{ Güven Aralığı } \\
\hline & & & & & & & $\begin{array}{l}\text { Alt } \\
\text { Sinır }\end{array}$ & $\begin{array}{l}\ddot{\text { Üst }} \\
\text { Sinır }\end{array}$ \\
\hline $\begin{array}{l}\text { Sabit Etkiler } \\
\text { Modeli }\end{array}$ & 27 & 19,62 & 0,00 & 147,39 & 50,99 & 0,952 & 0,86 & 1,04 \\
\hline $\begin{array}{l}\text { Rastgele } \\
\text { Etkiler Modeli }\end{array}$ & 27 & 9,44 & 0,00 & 147,39 & 50,99 & 1,120 & 0,85 & 1,29 \\
\hline
\end{tabular}

Homojenlik testi sonucunda Q istatistiksel değeri 147,395 olarak hesaplanmıştır. Ki-kare tablosundan \%95 anlamlılık düzeyinde 56 serbestlik derecesi ile kritik değer yaklaşık 50,993 olarak kabul edilmektedir. Bu araştırmada hesaplanan Q istatistiksel değeri (147,395), kritik değer olan 50,993'ten büyük olduğu için etki büyüklükleri dağılımının heterojen yapıya sahip olduğu söylenebilir. Buna göre etki büyüklükleri dağılımının heterojen olduğu ( $p=0,05$ olduğu için) belirlenmiştir. Homojenlik testi sonuçları kritik değerden yüksek çıktığı için rastgele etkiler modeli değerlendirilmiştir. Buna göre, araştırmaya dâhil edilen çalışmaların birleştirilmemiş etki büyüklükleri, varyans ve çalışma ağırlıkları Tablo 2'de gösterilmiştir. 
Tablo 3. Araştırmaya dâhil edilen çalışmaların etki büyüklüğü bulguları

\begin{tabular}{|c|c|c|c|c|}
\hline Araştırmacı & Çalışma Alanı & Etki Büy. & $p$ & $\begin{array}{l}\text { Çalışma } \\
\text { Ağgrlığı }\end{array}$ \\
\hline Kırmız1, 2006 & $\begin{array}{l}\text { Çoklu Zekâ Kuramına Dayalı } \\
\text { İşirlikli Öğrenme }\end{array}$ & 2,465 & 0,000 & 4,39 \\
\hline Ayçin, 2009 & İsoteg & 2,380 & 0,000 & 3,25 \\
\hline Çakıroglu, 2007 & Üstbilişsel & 1,974 & 0,000 & 3,98 \\
\hline Kaya, 2006 & Öğrenme Stratejileri & 1,563 & 0,000 & 3,31 \\
\hline Kırmızı, 2006 & Çoklu Zekâ Kuramı & 1,461 & 0,000 & 3,91 \\
\hline Pilten, 2007 & Anafikir Bulma Stratejsi & 1,461 & 0,000 & 3,81 \\
\hline Belet, 2005 & Not Alma & 1,436 & 0,000 & 3,37 \\
\hline Kılıç, 2015 & İşbirlikli Öğrenme & 1,358 & 0,000 & 3,99 \\
\hline Oruç, 2012 & Öz Düzenleme & 1,344 & 0,000 & 3,64 \\
\hline Ulu, 2011 & Rutin Olmayan Problemler & 1,344 & 0,000 & 3,81 \\
\hline Sulak, 2014 & Süreçsel Model & 1,303 & 0,000 & 3,75 \\
\hline Karasu, 2013 & Diyoloğa Dayalı Öğrenme & 1,290 & 0,000 & 3,73 \\
\hline Kırmızı, 2006 & İşbirlikli Öğrenme & 1,274 & 0,000 & 3,98 \\
\hline Kayıran, 2007 & Çoklu Zekâ Kuramı & 1,268 & 0,000 & 3,91 \\
\hline Kuşdemir, 2014 & Doğrudan Öğretim & 1,248 & 0,000 & 3,57 \\
\hline Palamut, 2008 & Hikaye Okuma Tekniği & 1,233 & 0,000 & 3,90 \\
\hline Kanmaz, 2012 & İsoat & 1,088 & 0,000 & 3,70 \\
\hline Epçaçan, 2008 & Tiöd & 1,077 & 0,000 & 4,03 \\
\hline Şahin, 2012 & Hikaye Haritası & 0,999 & 0,001 & 3,67 \\
\hline Epçaçan, 2008 & İşbirlikli Öğrenme & 0,889 & 0,000 & 3,95 \\
\hline Bozpolat, 2012 & BİOK Hikaye Haritası & 0,870 & 0,001 & 3,86 \\
\hline Çayır, 2011 & Çoklu Zekâ Kuramı & 0,706 & 0,041 & 3,70 \\
\hline Bulut, 2013 & Etkin Dinleme & 0,429 & 0,017 & 3,81 \\
\hline Güneyli, 2007 & Etkin Öğrenme & 0,278 & 0,000 & 3,87 \\
\hline Şen, 2003 & Biliş Ötesi Strateji & 0,195 & 0,179 & 4,14 \\
\hline Bayrakçı, 2004 & $\begin{array}{l}\text { Okuduğunu } \quad \text { Anlama } \\
\text { Stratejileri }\end{array}$ & 0,054 & 0,000 & 3,87 \\
\hline Mazi, 2008 & $\begin{array}{l}\text { Hikaye Yoluyla Öğrenme } \\
\text { Genel Etki }\end{array}$ & $\begin{array}{l}0,049 \\
1,120\end{array}$ & $\begin{array}{l}0,832 \\
0,000\end{array}$ & 3,99 \\
\hline
\end{tabular}


Hesaplamalar sonucunda meta-analize dâhil edilen 27 çalışmadaki veriler rastgele etkiler modeline göre; 0,114 standart hata ve \%95'lik güven aralığının üst sınırı 1,295 ve alt sınırı 0,850 ile etki büyüklüğü değeri $E S=1,120$ olarak hesaplanmıştır. Etki büyüklüğü değerinin Cohen'in (1988) sınıflamasına göre geniş aralıkta yer aldığı, buna göre okuduğunu anlamada kullanılan stratejilerin okuduğunu anlamaya etkisinin olumlu yönde olduğu söylenebilir. Tablo 3 incelendiğinde analize dâhil edilen çalışmaların etki büyüklüklerinin pozitif çıkması deney gruplarının lehine bir sonuçtur. Bu nedenle, okuduğunu anlama sürecinde stratejileri kullanmanın etkili olduğu söylenebilir.

Şekil 1. Çalışmaların etki büyüklüğüne göre dağılımları

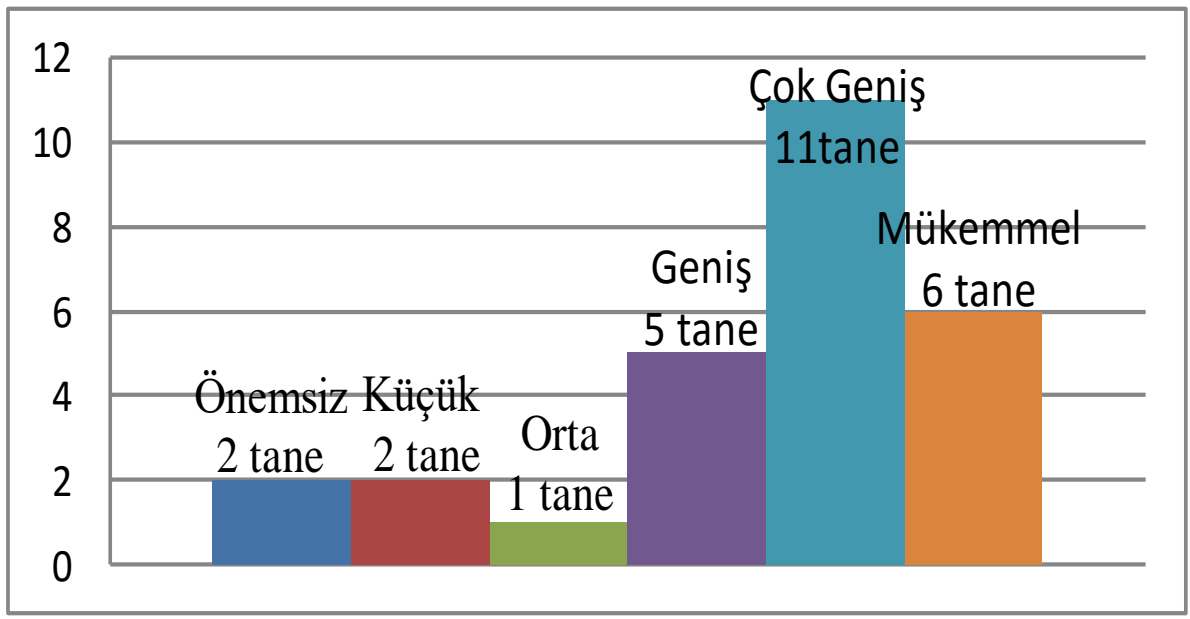

Şekil 1 incelendiğinde 5 çalışmanın mükemmel düzeyde etki büyüklüğüne sahipken, 11 çalışmanın çok geniş düzeyde etki büyüklüğüne sahip olduğu görülmüştür. Çalışmalardan 5 tanesi geniş düzeyde, 1 tanesi orta düzeyde, 2 tanesi küçük düzeyde etki büyüklügüne sahipken 2 tanesi önemsiz düzeyde etki büyüklüğüne sahiptir. 
Tablo 4. Okuduğunu anlama alanında yapılan tezlerin uygulanan stratejilere göre etki büyüklükleri

\begin{tabular}{lll}
\hline Uygulanan Yöntem, Teknik, Strateji & N & Etki Büyüklüğ̈̈ \\
\hline Coklu zekâ kuramına dayalı işbirlikli öğrenme & 1 & 2,465 \\
İSOTEG Tekniği & 1 & 2,380 \\
Üstbilişsel strateji & 1 & 1,974 \\
Not alma & 1 & 1,436 \\
Öz Düzenlemeli Öğrenme & 1 & 1,344 \\
Rutin olmayan & 1 & 1,344 \\
Süreçsel Model & 1 & 1,319 \\
Diyoloğa Dayalı & 1 & 1,290 \\
Ana Fikir Bulma & 1 & 1,272 \\
Doğrudan Öğretim & 1 & 1,248 \\
Çoklu Zekâ & 3 & 1,207 \\
İşbirlikli Öğrenme & 3 & 1,152 \\
İSOAT Tekniği & 1 & 1,088 \\
TíOD & 1 & 1,077 \\
Hikâye Haritası & 2 & 0,926 \\
Hikâye Okuma & 2 & 0,623 \\
Okuduğunu Anlama Stratejileri & 3 & 0,619 \\
Etkin Dinleme Eğitimi & 1 & 0,429 \\
Biliş Ötesi strateji & 1 & 0,195 \\
\hline Arastrmava & &
\end{tabular}

Araştırmaya dâhil edilen çalışmalarda en çok çoklu zekâ kuramı ve işbirlikli öğrenmenin ele alındığı ve etki büyüklüğüne bakıldığında ise en etkili okuduğunu anlama stratejisinin çoklu zekâ kuramına dayalı işbirlikli öğrenmenin olduğu görülmüsstür. En az etki büyüklüğüne sahip olan okuduğunu anlama stratejisi ise biliş ötesi stratejidir.

Tablo 5. Okuduğunu anlamaya yönelik lisansüstü tezlerin türlerine göre etki büyüklükleri

\begin{tabular}{lll}
\hline Tez Türü & N & Etki Büyüklüğü \\
\hline Yüksek Lisans & 11 & 1,001 \\
Doktora & 16 & 1,208 \\
\hline
\end{tabular}

Okuduğunu anlamaya yönelik lisansüstü tezlerin türlerine göre dağılımına bakıldığında yüksek lisans tezlerinin geniş düzeyde etki büyüklüğüne sahip olduğu, doktara tezlerinin ise çok geniş düzeyde etki büyüklüğüne sahip olduğu görülmüştür. Homojenlik testi sonucunda, yapılan çalışmaların türüne göre hesaplanan etki büyüklük değerleri arasında anlamlı bir farklılık bulunmuştur $(p=0,016)$. 
Tablo 6. Okuduğunu anlama alanında yapılan lisansüstü tezlerin uygulanan sınıf düzeylerine göre etki büyüklüğü

\begin{tabular}{lll}
\hline Sınıf & N & Etki Büyüklüğ̈̈ \\
\hline 4.Sinıf & 11 & 1,183 \\
5.Sinıf & 16 & 1,075 \\
\hline
\end{tabular}

Okuduğunu anlamaya yönelik lisansüstü tezlerin uygulanan öğrenim düzeylerine göre dağılımına bakıldığında dördüncü sınıfların çok geniş düzeyde etki büyüklüğüne sahip olduğu, beşinci sınıfların ise geniş düzeyde etki büyüklüğüne sahip olduğunu görülmüştür. Diğer yandan, homojenlik testi sonucunda, yapılan çalışmaların sınıf düzeyine göre hesaplanan etki büyüklük değerleri arasında anlamlı bir farklılık bulunmamıştır $(\mathrm{p}=0,961)$.

Tablo 7. Okuduğunu anlama alanında yapılan lisansüstü tezlerin yıllara göre etki büyüklükleri

\begin{tabular}{lll}
\hline Yıllar & N & Etki Büyüklüğü \\
\hline $2003-2008$ aras1 & 15 & 1,163 \\
$2009-2015$ aras1 & 12 & 1,148 \\
\hline
\end{tabular}

Okuduğunu anlamaya yönelik tezlerin yıllara göre dağılımına bakıldığında 2003-2008 yılları arası ile 2009-2015 yılları arasında yapılan tezlerin etki büyüklükleri mükemmel düzeyde olduğu görülmüştür. Homojenlik testi sonucunda, yapılan çalışmaların yıllarına göre hesaplanan etki büyüklük değerleri arasında anlamlı bir farklılık bulunmamıştır $(\mathrm{p}=0,841)$.

Tablo 8. Okuduğunu anlama alanında yapılan lisansüstü tezlerin uygulama sürelerine göre etki büyüklükleri

\begin{tabular}{lll}
\hline Uygulamada Süreleri & N & Etki Büyüklüğü \\
\hline $0-21$ saat & 9 & 0,890 \\
$22-50$ saat & 9 & 1,086 \\
$51-120$ saat & 9 & 1,422 \\
\hline
\end{tabular}

Okuduğunu anlama alanında yapılan lisansüstü tezlerin uygulama sürelerine göre etki büyüklüğüne bakıldığında 0-21 saat arasında uygulanan araştırmaların $\mathrm{ES}=0,890$ ile en az etki büyüklüğüne, deney süresi 22-50 saat aralığında olan araştırmaların $\mathrm{ES}=1,086$ ile geniş düzeyde etki büyüklüğüne ve 51-120 saat aralığında uygulanan okuduğunu anlama stratejilerinin $\mathrm{ES}=1,422$ ile çok geniş düzeyde etki büyüklüğüne sahip olduğu görülmüştür. Bu durum uygulama süresi arttıkça daha etkili okuduğunu anlama stratejilerinin uygulandığı göstermektedir. Homojenlik testi sonucunda, yapılan çalışmaların uygulama süresine göre hesaplanan etki büyüklük değerleri arasında anlamlı bir farklılık bulunmuştur $(\mathrm{p}=0,000)$. 


\section{TARTIŞMA SONUÇ ve ÖNERI}

\subsection{Tartışma}

Rastgele etkiler modeline göre yapılan analizler doğrultusunda çok geniş düzeyde, pozitif ve anlamlı bir etki büyüklüğü bulunmuştur. Mevcut araştırmanın bulguları, okuduğunu anlamada kullanılan stratejilerin geleneksel öğretim yöntemine oranla daha başarılı olduğunu göstermiştir. Alanyazında yalnızca yöntemlerden birini ele alan meta analiz çalışmaları bulunmaktadır. Yurt ve Polat (2015) çoklu zekâ öğretim uygulamaları, Camnalbur (2008) ve Demir (2013) bilgisayar destekli öğretim, Okursoy G. (2009) kavram haritaları, Özdemirli (2011) ve Jonhnson, Johnson ve Stanne (2000) işbirliğine dayalı öğrenme yöntemlerinin daha etkili olduğunu yaptıkları meta analiz çalışmaları ile ortaya koymuşlardır. Benzer biçimde Çelik (2013) ve Topan (2013) tarafından yapılan meta-analiz çalışmasında da matematik dersinde kullanılan yöntemlerin öğrenci başarısını artırdığı sonucuna ulaşılmıştır. Bunlara ek olarak bu araştırmada da incelenen yöntem ve tekniklerin akademik başarı üzerindeki etkisinin deneysel araştırmalarla belirlendiği görülmüştür.

Okuduğunu anlama stratejilerinin etkililiği çalışmaların yapıldığı yıllara bağlı olarak değişmemektedir. Bu da gösterir ki yıllar ilerledikçe daha etkili okuduğunu anlama stratejileri uygulanmamıştır. Demir'in (2013) yaptığı bilgisayar destekli matematik öğretiminin akademik başarıya etkisi de yıllara göre anlamlı bir farklılık göstermemiştir.

Araştırmaya dâhil edilen 27 çalışma 12 farklı üniversitede üretilmiştir. Bunun 7'sinin Gazi Üniversitesinde olduğu görülmüştür. Sunğur (2015)'un yaptığı meta analiz çalışmasında da en fazla çalışmanın üretildiği üniversite Gazi Üniversitesi'dir.

Yöntem olarak en etkili yöntem çoklu zekâ kuramına dayalı iş birlikli öğrenmenin kullanılmasıdır. Diğer etkili yöntemler ise İSOTEG tekniği ve üstbilişsel stratejidir. Davis'ın (2010) yaptığı anlama stratejilerinin meta analizi çalışmasında en etkili yöntemler karşılıklı öğretim, akran destekli öğrenme stratejisi, düşünmeye yönelik eğitim, işlemsel stratejileri eğitimi ve kavram odaklı okuma öğretimidir. Sencibaugh'ın (2007) yaptığı okuma güçlüğü çeken öğrencilere uygulanan okuduğunu anlama meta analizinde en etkili yöntemin paragraf yakın anlam (paragraph restatement) stratejisi olduğu bulunmuştur. Swanson'ın (1999) yaptığı kapsamlı bir meta-analizde bilişsel ve doğrudan öğretim stratejisi en etkili bulunmuştur.

Araştırma kapsamına alınan çalışmalarda en fazla çoklu zekâ kuramı ve işbirliğine dayalı öğrenmenin uygulandığı görülmüştür. Yaşar (2015) tarafindan yapılan meta-analiz çalışmasında da en fazla çoklu zekâ kuramı ve işbirliğine dayalı öğrenme ele alınmıştır.

Uygulama süresi açısından bakıldığında uygulama süresi uzun olan çalışmaların daha büyük etki büyüklüğüne sahip olduğu görülmüştür. Literatüre bakıldığında farklı öğretim uygulamalarının uygulama süresine göre başarı üzerindeki etkisini inceleyen çalışmalar bulunmuştur. Ginns, Martin ve Marsh (2013) tarafindan yapılan konuşma stillerine yönelik hazırlanan öğretim tasarımlarının başarı üzerindeki etkisini inceleyen meta analizde uygulama süresine göre konuşma becerisinin farklılaştığı belirtilmiştir. Yine Yurt ve Polat'ın (2015) yaptığı çoklu zekâ uygulamalarının akademik başarı üzerindeki etkisi uygulama süresine göre farklılaşmıştır. Öte yandan işbirlikli öğrenme yönteminin matematik başarısı üzerindeki etkililiği (Özdemirli, 2011) uygulama süresine göre farklılaşmamıştır. 


\subsection{Sonuçlar}

Araştırmanın amacı doğrultusunda incelenen 115 tez arasından 24 tez üzerinde inceleme ve analiz yapılmıştır. Elde edilen sonuçlar aşağıda sıralanmıştır.

Rastgele etkiler modeline göre yapılan analizler doğrultusunda; 0.120 standart hata ile etki büyüklüğü değeri ES=1,120 olarak hesaplanmıştır. Bu değer, Cohen ve diğerlerinin (1988) sınıflandırmasına göre çok geniş düzeyde, pozitif ve anlamlı bir etki büyüklügüdür. Mevcut araştırmanın bulguları, okuduğunu anlamada kullanılan stratejilerin geleneksel öğretim yöntemine oranla daha başarılı olduğunu göstermiştir

Araştırmaların 11 tanesi yüksek lisans, 13 tanesi doktora tezidir. Yüksek lisans tezlerinin etki büyüklüğü $\mathrm{ES}=1.001$ yani geniş düzeyde, doktora tezlerinin etki büyüklüğü $\mathrm{ES}=1.208$ yani çok geniş düzeyde belirlenmiştir. Homojenlik testi sonucuna göre, çalışmaların türlerine göre hesaplanan etki büyüklük değerleri arasında anlamlı bir farklılık saptanmıştır. Buna göre doktora tezlerinde daha etkili okuduğunu anlama stratejilerin kullanıldığı ve yüksek lisans tezlerine göre daha kapsamlı araştırma yapıldığı söylenebilir.

Yıllara bakıldığında 2003 ve 2008 arası 15 araştırma yapılmışken 2008'den sonra bu 11'e düşmüş 2010 yılında bu konuda deneysel bir araştırma yapılmamıştır. Etki büyüklüğüne bakıldığında ise birbirine yakın değerler bulunmuştur. Bu durumda, okuduğunu anlama stratejilerinin etkililiği çalışmaların yapıldığı yıllara bağlı olarak değişmemektedir. $\mathrm{Bu}$ durum yıllar ilerledikçe daha etkili okuduğunu anlama stratejilerinin uygulanmadığını göstermiştir.

Araştırmaya katılan çalışmaların tümünün okuduğunu anlamayı arttırmada pozitif bir etkiye sahip olduğu görülmüştür. En fazla Kırmızı'nın (2006) yaptığı araştırma okuduğunu anlamada başarılı olmuştur. Aynı zamanda Kırmızı'nın (2006) uygulama süresinin yüksek olması çalışmanın etki büyüklüğünü arttırmada etkili olduğu söylenebilir. Yöntem olarak ise en etkili yöntem çoklu zekâ kuramına dayalı iş birlikli öğrenmenin kullanılmasıdır. Diğer etkili yöntemler ise İSOTEG Tekniği ve Üstbilişsel Stratejidir.

En az etki büyüklüğüne sahip okuduğunu anlama stratejisi ise 2003 yılında yapılan biliş ötesi stratejidir. Bu araştırmanın etki büyüklüğünün küçük düzeyde olması alanında yapılan ilk deneysel çalışma olduğu için olabilir.

Araştırma kapsamına alınan çalışmalarda en fazla çoklu zekâ kuramı ve işbirliğine dayalı öğrenmenin uygulandığı görülmüştür.

Okuduğunu anlamaya yönelik lisansüstü tezlerin uygulanan öğrenim düzeylerine göre dağılımına bakıldığında dördüncü sınıf çok geniş düzeyde etki büyüklüğüne sahipken, beşinci sınıf geniş düzeyde etki büyüklüğüne sahiptir.

Meta analize dâhil edilen araştırmaların farklı sürelerde uygulamalarının yapıldığ 1 görülmüştür. 0-21 saat arasında uygulanan araştırmaların küçük düzeyde etki büyüklüğüne, deney süresi 22-50 saat aralığında olan araştırmaların geniş düzeyde etki büyüklüğüne ve 51-120 saat aralığında uygulanan okuduğunu anlama stratejilerinin çok geniş düzeyde etki büyüklüğüne sahip olduğu görülmüştür. Diğer yandan, homojenlik testi sonucuna göre, çalışmaların uygulama süresine göre hesaplanan etki büyüklük değerleri arasında anlamlı bir farklılık saptanmıştır. Buna göre uygulama süresi açısından bakıldığında uygulama süresi uzun olan çalışmaların daha büyük etki büyüklüğüne sahip olduğu görülmüştür. 


\section{3. Öneriler}

Çalışmadan elde edilen sonuçlarla Türkiye'de okuma anlama stratejisiyle ilgili yayımlanan deneysel araştırmaların akademik başarı üzerindeki etki büyüklükleri çeşitli değişkenler açısından ortaya konulmaya çalışılmıştır. Bu çalışmanın sonuçlarının yeni araştırmalar için yol gösterici olacağına inanılmaktadır. Bu doğrultuda, konuyla ilgili yapılabilecek benzer veya ilişkili çalışmalar için şu öneriler sunulmuştur.

- Uygulanan okuduğunu anlama stratejisinin uygulama süresi arttıkça etki büyüklüğünün artması gelecekte okuduğunu anlamaya yönelik deneysel çalışma yapacak araştırmacılar için öneri niteliğindedir. Özellikle "51 saat ve üzeri" uygulama süresine sahip çalışmaların başarı üzerindeki etkisi daha yüksek bulunmuştur. Uygulama süresinin artırılmasıyla, okuduğunu anlama üzerindeki etkisinin artabileceği göz önünde bulundurulmalıdır.

- Meta analiz araştırmaları çok daha fazla yayına ulaşıldığı takdirde nitelik kazanmaktadır. Böylece araştırmanın güvenilir sonuçlar vermesi beklenir. Araştırmada yüksek lisans ve doktora tezlerinin yanında tez, makale, bildiri gibi araştırmalara ulaşılması ülkemizde okuduğunu anlama stratejilerinin etkisini daha net ortaya koyacaktır.

- Okuduğunu anlama stratejilerinin; kalıcılık, tutum ve diğer duyuşsal özellikler üzerindeki etkisi de meta-analiz yöntemi ile incelenebilir.

- $\quad \mathrm{Bu}$ çalışma dördüncü ve beşinci sınıflarla sınırlandırılmıştır. Diğer sınıf düzeylerinde yapılan okuduğunu anlama stratejilerinin etkisi dâhil edilerek daha genel bir sonuca ulaşılabilir. 


\section{KAYNAKLAR}

Abramson, J. H., \& Abramson, Z. H. (2007). Making sense of data. A self instruction manual on the interpretation of epidemiological data. New York: Oxford University Press.

Ayçin, A. (2009). ISOTEG tekniğinin beşinci sınıf öğrencilerinin okuduğunu anlama başartsı ve okumaya yönelik tutumlarl üzerine etkisi YIBBO örneği. Yayımlanmamış yüksek lisans tezi, Çukurova Üniversitesi, Adana.

Bayrakçı, R. (2004). İlköğretim 4.sınıf Türkçe dersinde uygulanan okuduğunu anlama ve problem çözme stratejilerinin ögrenci başarılarına etkisi. Yayımlanmamış yüksek lisans tezi, Selçuk Üniversitesi, Konya.

Belet, D. (2005). Öğrenme stratejilerinin okuduğunu anlama ve yazma becerileri ile Türkçe dersine ilişkin tutumlara etkisi. Yayımlanmamış doktora tezi, Anadolu Üniversitesi, Eskişehir.

Bozpolat, E. (2012). Türkçe dersinde birleştirilmiş işbirlikli okuma ve kompozisyon tekniği ile kullanılan hikaye haritası yönteminin öğrencilerde okuduğunu anlama becerisini geliştirmeye etkisi. Yayımlanmamış doktora tezi, Fırat Üniversitesi, Elazı ̆̆.

Bulut, B. (2013). Etkin dinleme eğitiminin dinlediğini anlama, okuduğunu anlama ve kelime hazinesi üzerine etkisi. Yayımlanmamış yüksek lisans tezi, Adnan Menderes Üniversitesi, Aydın.

Camnalbur, M., \& Erdoğan, Y. (2008). Bilgisayar destekli öğretimin etkililiği üzerine bir meta analiz çalışması: Türkiye örneği. Kuram ve Uygulamada Eğitim Bilimleri, 8, 497-505.

Cohen, J. (1988). Statistical power analysis for the behavioral sciences. Hillsdale, NJ: Lawrence Erlbaum Associates.

Çakıroğlu, A. (2007). Üstbilişsel strateji ögrretimi ile okuduğunu anlama başarı düzeyi düşük olan ögrencilerin okuduğunu anlama erişi artırımına etkisi. Yayımlanmamış doktora tezi, Gazi Üniversitesi, Ankara.

Çayır, N. B. (2011). Illköğretim 4. sinıf Türkçe dersi öğretiminde çoklu zekâ uygulamalarını ögrencilerin okuduğunu anlama ve yazılı anlatım becerileriyle ilgili deneysel bir araştırma. Yayımlanmamış yüksek lisans tezi, Dokuz Eylül Üniversitesi, İzmir.

Çelik, S. (2013). Illköğretim matematik derslerinde kullanılan alternatif öğretim yöntemlerinin akademik başarıya etkisi: Bir meta analiz çalışması. Yayımlanmamış yüksek lisans tezi, Osmangazi Üniversitesi, Eskişehir.

Davis, D. S. (2010). A meta - analysis of comprehension strategy instruction for upper elementary and middle school students. Unpublished thesis. Vanderbilt University, Tennessee.

Demir, S.(2013). Bilgisayar destekli matematik öğretiminin (BDMO) akademik başarıya etkisi. Yayımlanmamış yüksek lisans tezi, Gaziosmanpaşa Üniversitesi, Tokat.

Dinçer, S. (2014). Eğitim bilimlerinde uygulamalı meta-analiz. Ankara: Pegem A.

Durlak, J. A. (1995). Reading and understanding multivariate statistics. Washington, DC: American Psychological Association. 
Epçaçan, C. (2008). Okuduğunu anlama stratejilerinin bilişsel ve duyuşsal öğrenme ürünlerine etkisi. Yayımlanmamış doktora tezi, Hacettepe Üniversitesi, Ankara.

Ginns, P., Martin, A. J., \& Marsh, H. W. (2013). Designing instructional text in a conversational style: A meta-analysis. Educational Psychology Review, 25(4), 445-472.

Güneş, F. (2009). Hızlı okuma ve anlamı yapılandırma. Ankara: Nobel Yayın Dağıtım.

Güneyli, A. (2007). Etkin öğrenme yaklaşımının anadili ĕ̆itiminde okuma ve yazma becerilerini geliştirmeye etkisi. Yayımlanmamış doktora tezi, Ankara Üniversitesi, Ankara.

Gürses, R. (1996). Okuma anlama. Ataturk Kultur, Dil ve Tarih Yuksek Kurumu Bülteni, 28(9), 98-103.

Igel, C. (2010). The effect of cooperative learning instruction on $K-12$ student learning: A meta-analysis of quantitative studies from 1998 to 2009. Yayımlanmamış doktora tezi, Univerity of Virginia, Charlottesville.

Johnson, D. W., Johnson, R. T., \& Stanne, M. E. (2000). Cooperative learning methods: A meta-analysis. Minneapolis, MN:University of Minnesota Press.

Kanmaz, A. (2012). Okuğunu anlama stratejisi kullanımının, okuduğunu anlama becerisi, bilişsel farkındalık, okumaya yönelik tutum ve kalıcılığa etkisi. Yayımlanmamış doktora tezi, Adnan Menderes Üniversitesi, Aydın.

Karasu, M. (2013). Diyaloğa dayall öğretim stratejilerinin okuma tutum ve becerilerini geliştirmeye etkisi. Yayımlanmamış doktora tezi, Gazi Üniversitesi, Ankara.

Kavcar, C., Oğuzkan, F., \& Sever, S. (1994). Turkçe öğretimi. Ankara: Engin Yayınc1lık.

Kaya, F. (2006). Ilköğretim dördüncü sınıf türkçe dersinde bazl ögrenme stratejilerinin tutum ve okuduğunu anlamaya etkisi. Yayımlanmamış yüksek lisans tezi, Mustafa Kemal Üniversitesi, Hatay.

Kayıran, B. (2007). Çoklu zekâ kuramı destekli kubaşık öğrenme yönteminin türkçe dersine ilişkin tutum ve okuduğunu anlamaya yönelik akademik başarı üzerindeki etkisi. Yayımlanmamış yüksek lisans tezi, Çukurova Üniversitesi, Adana.

Kılıç, A. (2004). Işsbirlikli Öğrenme, Okuduğunu Anlama, Strateji Kullanımı ve Tutum. Yayımlanmamış doktora tezi, Dokuz Eylül Üniversitesi, İzmir.

Kırmızı, F. S. (2006). İlköğretim 4. sınıf Türkçe öğretiminde çoklu zekâ kuramına dayalı işbirlikli ögrenme yönteminin erişi, tutumlar, ögrenme stratejileri ve çoklu zekâ alanları üzerindeki etkileri. Yayımlanmamış doktora tezi, Dokuz Eylül Üniversitesi, İzmir.

Kuşdemir, Y. (2014). Doğrudan Öğretim Modeli’nin ilkokul dördüncü sınıf ögrencilerinin okuduğunu anlama becerilerine etkisi. Yayımlanmamış doktora tezi, Gazi Üniversitesi, Ankara.

Mazı, A. (2008). Hikayeler yoluyla düşünmenin ilköğretim 5. sınıf Türkçe dersinde okuduğunu ve dinlediğini anlamaya etkisi. Yayımlanmamış yüksek lisans tezi, Mustafa Kemal Üniversitesi, Hatay. 
National Reading Panel (NRP), (2000). Teaching children to read: An evidencebased asessment of the scientific research literature on reading and its implications for reading instruction: report of the subgroups. Retrieved fromhttps://www.nichd.nih.gov/publications/pubs/nrp/documents/report.pdf (10.12.2015)

Okursoy, F. G. (2009). Kavram haritaları öğretim stratejisinin ögrenci başarısına etkisi: Bir meta analiz çalışması. Yayımlanmamış yüksek lisans tezi, Marmara Üniversitesi, İstanbul.

Oruç, A. (2012). Öz düzenlemeli ögrenmenin okuduğunu anlamaya tutuma ve üst bilişsel düşünme etkisi. Yayımlanmamış yüksek lisans tezi, Bülent Ecevit Üniversitesi, Zonguldak.

Özcan, Ş. (2008). Eğitim yöneticisinin cinsiyet ve hizmet içi eğitim durumunun göreve etkisi: Bir meta analitik etki analizi. Yayınlanmamış doktora tezi, Marmara Üniversitesi/Eğitim Bilimleri Enstitüsü, İstanbul.

Özdemirli, G. (2011). Işsbirlikli öğrenme yönteminin öğrencinin matematik başarısı ve matematiğe ilişkin tutumu üzerindeki etkililiği: Bir meta-analiz çalışması. Yayımlanmamış yüksek lisans tezi, Çukurova Üniversitesi, Adana.

Razon, N. (1980). Okuma Bozuklukları ve Nedenleri. Pedagoji Dergisi, Sayı 1.

Palamut, İ. (2008). Hikâye okumanın ilköğretim öğrencilerinin yaratıcılık düzeylerine ve akademik başarılarına etkisi. Yüksek lisans tezi, Dokuz Eylül Üniversitesi, İzmir.

Pilten, G. (2007). Ana fikir bulma stratejisi ögretiminin ana fikir bulma ve okudugunu anlamaya etkisi, Yüksek lisans tezi, Gazi Üniversitesi, Ankara.

PISA 2012 Projesi Ulusal Nihaî Rapor, M. E. B. Eğitimi Araştırma ve Geliştirme Dairesi Başkanlığı, Milli Eğitim Basımevi, Ankara.

Sağlam, M., \& Yüksel, İ. (2007). Program değerlendirmede meta-analiz ve metadeğerlendirme yöntemleri. Dumlupınar Üniversitesi Sosyal Bilimler Dergisi, $18,175-188$.

Sencibaugh, J. M. (2007). Meta-analysis of reading comprehension interventions for students with learning disabilities: Strategies and implications. Reading Improvement, 44, 6-22.

Sidekli, S. (2005), İlköğretim Beşinci Sınıf Öğrencilerinin Öğretici ve Öyküleyici Metinlere Göre Okuduğunu Anlama Becerilerinin Sınanması. Yayımlanmamış yüksek lisans tezi). Gazi Üniversitesi, Ankara.

Sidekli, S. (2010). İlköğretim 5. sinıf ögrencilerinin okuma ve anlama becerilerinin geliştirilmesi: eylem araştırması. Yayınlanmamış doktora tezi, Gazi Üniversitesi, Ankara.

Sidekli, S., \& Yangın, S. (2005). Okuma güçlüğü olan öğrencilerin okuma becerilerinin geliştirilmesine yönelik bir uygulama. Atatürk Üniversitesi Kazım Karabekir Eğitim Fakültesi Dergisi, 11, 393-413.

Sulak, S. E. (2014). Süreçsel modelle bilgilendirici metin öğretiminin okuduğunu anlama becerilerine etkisi. Yayımlanmamış doktora tezi, Gazi Üniversitesi, Ankara. 
Sunğur, B. (2012). Bilgisayar destekli öğretimin ilköğretim ögrrencilerinin akademik başarısına etkisi üzerine meta analiz çalışması. Yayımlanmamış yüksek lisans tezi, Zirve Üniversitesi, Gaziantep.

Swanson, H. L. (1999). Reading research for students with LD: A meta-analysis of intervention outcomes. Journal of Learning Disabilities, 32(6), 504-532.

Şahin, M. C. (2005). Internet tabanll uzaktan eğitimin etkililiği: Bir meta-analiz çalışması. Yayımlanmamış yüksek lisans tezi, Çukurova Üniversitesi, Adana.

Şahin, İ. (2012). İlköğretim 5.sınıf öğrencilerinin hikaye edici metinlerde özetleme ve ana fikir bulma becerileri üzerinde hikaye haritalarının etkisi. Yayımlanmamış yüksek lisans tezi, Akdeniz Üniversitesi, Antalya.

Şen, Ş. (2003). Biliş ötesi stratejilerini ilköğretim okulu beşinci sinıf öğrencilerinin okuduğunu anlama düzeylerine etkisi. Yayımlanmamış doktora tezi, Gazi Üniversitesi, Ankara.

Topan, B. (2013). Matematik öğretiminde öğrenci merkezli yöntemlerin akademik başart ve derse yönelik tutum üzerindeki etkililiği: Bir meta-analiz çalışmast. Yayımlanmamış yüksek lisans tezi, Kocaeli Üniversitesi, Kocaeli.

Ulu, M. (2011). İlköğretim beşinci sınıf ögrencilerinin rutin olmayan problemlerde yaptlkları hataların belirlenmesi ve giderilmesine yönelik bir uygulama. Yayımlanmamış doktora tezi, Gazi Üniversitesi, Ankara.

Yaşar, Ş., Köse, T. Göz, L., \& Bayır, Ö. (2015). Sosyal bilgiler dersinde öğrenci merkezli öğretme-öğrenme süreçlerinin etkililiği: Bir meta analiz çalışması. Anadolu Journal of Educational Sciences International, 5, 38-56.

Yurt, E., \& Polat, S. (2015). The effectiveness of multiple intelligence applications on academic achievement: A meta-analysis. Journal of Social Studies Education Research, 6(1), 84-122. 


\section{EXTENDED ABSTRACT}

\section{Purpose}

In this study, the effects of some of the studies that examine the effects of reading comprehension strategies on learners reading comprehension ability are aimed to be come together. Additionally, effect size of these studies is examined in terms of learners' reading comprehension strategies, thesis types, theses' years and teaching process differences with the help of a meta-analysis method.

\section{Method}

Meta-analysis method presents some quantitative data examining the previous experimental studies and also, this method generalizes all of the study results and as in this way, there is a more comprehensible study in the literature. In this study, the main aim of using metaanalysis method is to reveal the effects of reading comprehension on learners clearly. As coming together, the same results and generalizing these results are some of the basic properties of the meta-analysis method.

While determining the studies covered in the meta-analysis method, some different criteria are used. These are, firstly, the years of a study; that is in this study, the experimental studies conducted between 2000-2015 years are used. Secondly, studies consisting of an experimental group and control group are selected. Additionally, the studies having enough sample and universe, standard deviation, arithmetic mean and the studies just conducted in 4 . and 5. grade students are determined for this study. With the help of these criteria, from the studies conducted in 2000-2015, 24 studies are determined. The findings of these studies are significant to reveal the effects of reading comprehension strategies on learners' learning process and also these findings are important for the further studies. In this study, descriptive analysis and experimental meta-analysis methods are used. In descriptive analysis, the years of the studies, the types of the studies, universities and the frequency results of the studies in terms of methods are determined. As for experimental meta-analysis, Comprehensive Meta Analysis (CMA) program is used. With the help of CMA 2.2 program, firstly heterogeneousness test is completed. This test is very important because it is used to determine the model that will be used to reveal general effects. In the heterogeneousness test, if $p$-value is smaller than 0,05 or $Q$-value is bigger than df-value in chi square distribution, then it means the studies used in this study is heterogeneous. That is, these studies are not similar to each other. In this manner, the analysis could be conducted in random-facts model.

\section{Results}

The analysis is conducted in terms of random facts model. As a result of the calculations, the average effect size of 24 studies included in meta-analysis in order to determine the effect of reading comrehension strategies on success was found to be 1,120 . This value shows a large effect according to Cohen's (1988) classification. It was found that reading comrehension strategies in the studies were carried out during different periods. In order to determine whether the effect of these practices on success differentiate according to implementation period, the studies were classified under tree groups according to their implementation period as " 21 hours and less", "22-50 hours" and "51 hours and more". As a result of the analysis when the implementation period becomes longer, the effect of reading comrehension strategies on success increases.

\section{Discussion}

The results of the meta-analysis suggest that reading comprehension strategies leads to greater academic achievement than traditional reading methods. This result shows a consistency with the results of different meta-analysis studies that examine the effect of various instructional methods on success (Camnalbur, 2008; Çelik, 2013; Demir, 2013; Özdemirli, 2011; Jonhnson, Johnson, \& Stanne, 2000; Topan, 2013; Yurt \& Polat, 2015). In this research, the effect of reading comprehension strategies on success increase as the implementation period becomes longer. There are some studies in the literature that examine the effect of various instructional practices on success according to implementation period. The effect of the multiple intelligence practices on success differentiate significantly (Yurt \& Polat, 2015). 


\section{Conclusion}

As a result of the analysis, it is seen that reading comprehension strategies is more effective than the traditional models. All of the studies analyzed in this study suggest that reading comprehension strategies supports reading comprehension ability. It is seen that the studies analyzed in this study are conducted in different periods. It is clear that effect size changes in terms of study periods. The findings revealed that there was no significant difference in the effect sizes in terms of education 